\title{
Errata
}

\section{ALLELOPATHIC POTENTIAL OF SORGHUM (Sorghum bicolor): Isolation of Seed Germination Inhibitors}

\author{
FREDRIC R. LEHLE and ALAN R. PUTNAM
}

In Figure 2, there was a labeling error on the original drawing. On the left side Fraction III should be Fraction II and on the right, Fraction II should be Fraction III.

\author{
REFERENCE
}

Lehif, F. R. and Putman, A. R. 1983. J. Chem. Ecol. 9:1223-1234

\section{DEFENSIVE SECRETION OF THE PILL MILLIPEDE Glomeris marginata.}

\section{Fluid Production and Storage}

\author{
JAMES E. CARREL
}

There was a typographical error in the title of this article; namely, Glomeris was spelled with a terminal $c$ rather than with an $s$.

All future references to this article should of course employ the correct title which is shown above.

\section{REFERENCE}

Carrel, J.E. 1984. J. Chem. Ecol. 10: 41-51. 